\title{
'A long, slow and painful road': the Anglo-American Alliance and the Issue of Cooperation with the USSR from Teheran to D-Day
}

\author{
Martin Folly
}

\begin{abstract}
The Second World War Anglo-American alliance was less cohesive on the political side than the military. There were widening divergences between Britain and the United States with regard to the best way to handle cooperation with the USSR during 1944. There were some shared assumptions about the motivations of Soviet policy, but policy-makers in Britain and the US not only formulated different approaches, but consistently viewed their own ones to be more successful than those of their ally. There was an opportunity to coordinate polices in US Under-Secretary of State Edward Stettinius's mission to London in April 1944, but the fact that the issue was barely discussed is symptomatic of the situation. The British Foreign Office gained the backing of Winston Churchill in an attempt to forge ahead with pragmatic arrangements with the USSR. A satisfaction with their own efforts on both sides meant that the British and American bureaucracies made no serious and sustained attempt to coordinate their policies to the USSR through 1944, in contrast to the closeness of cooperation in other areas.
\end{abstract}

In April, 1944, the United States Under-Secretary of State, Edward R. Stettinius, conducted a three-week mission to London. The aim was to explore and clarify a range of political issues with America's British allies. It was an opportunity to confront divergences in policy since the Teheran conference ended in December 1943. A central political issue for the two allies was their handling of relations with the USSR. It is therefore striking that the mission made little attempt to consider Anglo-American policies on this issue. Instead, Stettinius observed in his report, with marked detachment, that 'the British seemed curiously unaware of the fact that American relations with Russia are at present enjoying less friction than their own.' ${ }^{1}$ This intriguing remark has been given little attention in the extensive literature on wartime Anglo-American relations. It highlights, however, an aspect of that relationship that can be overlooked as a result of viewing wartime BritishAmerican-Soviet interactions through a bilateral East-West prism - a tendency which has continued after the end of the Cold War and has distorted understanding of the relationships between the three major powers during the alliance period. ${ }^{2}$

The Stettinius mission and developments before and immediately following it show the limits of Anglo-American cooperation on one of the most vital issues that faced the two countries. It was a period when alliance politics were in a state of change and uncertainty. Scholars have drawn attention in recent years to the elements of contention as well as cooperation in the Anglo-American alliance, and have explored the management of these divergences. ${ }^{3}$ It has long been held that the British by 1944 had come to be more suspicious of future Soviet intentions, and

${ }^{1}$ Report of Stettinius Mission to Britain 7-29 April 1944 Foreign Relations of the United States 1944 volume III (hereafter FRUS1944:III), 10.

${ }^{2}$ Fraser J. Harbutt, Yalta 1945. Europe at the Crossroads (Cambridge, 2010), xii, 139-40.

3 Mark A. Stoler, Allies in War: Britain and American Against the Axis Powers 1940-1945 (London, 2005), cf David Reynolds, From War to Cold War. Churchill, Roosevelt, and the International History of the 1940s (Oxford, 2006), 51-2. 
had adopted a harder line in policy towards them. ${ }^{4}$ This is usually contrasted with President Franklin D. Roosevelt's continuing efforts to promote goodwill. This article will argue that there were indeed considerable differences between the two states on this fundamental issue, but they are not in fact reducible to such a straightforward dichotomy. Examination of interactions in the six months following the end of the Teheran Conference in December 1943 shows the allies not only aware of these differences but also knowingly eschewing the opportunity to construct a consensus. The little-known Stettinius mission thus serves as a good indicator of the nature of the Anglo-American political alliance.

By October 1943, the tide of war had changed in the Allies' favour. The Red Army was advancing rapidly through the Ukraine and had recently liberated Kiev. Anglo-American forces had landed in Italy, and American forces were beginning their advance through the Central Pacific. After a tense period of relations owing to the failure to launch a second front in Northern France, the United States-Great Britain-Soviet Union alliance moved into a new phase with a successful foreign ministers conference in Moscow in October, followed by the Big Three meeting at Teheran at the end of November. Roosevelt appointed one of his trusted envoys, W. Averell Harriman, to be ambassador at Moscow. ${ }^{5}$ The beginning of closer political cooperation in these summit meetings brought to the fore the question of whether the British and Americans were going to conduct their political relationship with the Soviets in the same combined manner as they were conducting their military affairs. At heart, as they considered the strategy for finally defeating Germany and Japan, and as they began to formulate their ideas about the post-war world, the issue they particularly needed to agree on, and from which positions on specific issues flowed, was whether the USSR, the former international outcast and source of revolutionary subversion, could or would be a cooperative partner and, if so, what was the best strategy to bring it about?

The key to answering this question lay in trying to understand the nature of the Soviet state and the aims and motivations of its leaders. The war brought increased contacts and sources of information, with far more Americans and Britons stationed in the USSR than ever before. The process of analysis was complicated by the crucial fact that the war was observably a transformative experience in the USSR, so that analysts were drawn to devote attention to the process of change. On the other hand, those witnessing these developments on the ground did so while themselves living under the restrictions imposed on foreign nationals in the USSR. This could have a profound impact on how these individuals perceived the Soviet Union, its leaders and its foreign policy. ${ }^{6}$

Having experienced the way the Soviet security forces responded to the alliance - by regarding foreign diplomats, journalists and soldiers as spies - those serving in Moscow were naturally struck by the cooperative manner displayed by Soviet Commissar for Foreign Affairs, Vyacheslav Molotov at the October foreign ministers meeting and by Josef Stalin at the Big Three meeting. ${ }^{7}$ After the Teheran

4 Terry H. Anderson, The United States, Britain and the Cold War, 1944-47 (Columbia, Missouri, 1981).

5 Rudy Abramson, Spanning the Century: The Life of W. Averell Harriman, 1891-1986 (New York, 1992), 350-1. Mary E. Glantz, FDR and the Soviet Union: The President's Battles Over Foreign Policy (Lawrence, KS, 2005), 145-48 argues that Roosevelt was seeking a new beginning in USUSSR relations: Harbutt contends that Harriman's appointment actually was of little practical significance, Harbutt, Yalta, 142.

6 Frank Costigliola, "Mixed Up and 'Contact': Culture and Emotion among the Allies in the Second World War', International History Review.20 (1998), 802-5.

7 Keith Sainsbury, The Turning Point. Roosevelt, Stalin, Churchill and Chiang Kai-shek, 1943. The Moscow, Cairo and Teheran Conferences (Oxford, 1985), 53-109; W. Averell Harriman and Elie Abel, Special Envoy to Churchill and Stalin, 1941-1946 (New York, 1975), 246-249; Harriman to Roosevelt 21 Oct. 1943 FRUS1943:I, 590 Clark Kerr to FO 5 Nov. 1943 F[oreign] O[ffice papers, UK National Archives] FO371/37031/N6575; Cadogan to Halifax 4 Nov. 1943 FO371/37030/N6447; Eden to Churchill 2 Nov. 1943 FO954/26A. 
conference ended in December, analysts in London and Washington were eager to ascertain whether the new Soviet style would last, and whether it signified a commitment to a more cooperative policy. Representatives in Moscow were encouraged to state their views on this. The question was seen to be intimately linked with other changes taking place in the USSR, notably the official approval of the Russian Orthodox Church, the emphasis on patriotic, rather than ideological, themes in state propaganda, constitutional changes ostensibly giving more autonomy to the republics, and social and cultural reforms that were moving Soviet society back towards more traditional practices. ${ }^{8}$

\section{American views}

Averell Harriman addressed and connected these various phenomena in the months immediately following the Teheran conference. He particularly focused on two issues that were being much discussed in the Moscow diplomatic community, and went on to draw out from them a recommendation as to how the Americans and British should act in order to influence the Soviets to continue to move in the direction of cooperation. The two issues were the post-war reconstruction needs of the USSR and the internal politics of the Soviet wartime leadership.

Soon after arriving in Moscow, Harriman asserted that the Soviet Government regarded reconstruction as its most important political, as well as economic, problem. It would therefore play an important role in allied relations with the USSR. ${ }^{9}$ The potential impact of Soviet post-war economic problems and reconstruction needs was to be a subject of speculation during 1944, and was a central element of estimates of Soviet intentions regarding cooperation with the allies. In both the American and British governments there was a broad consensus concerning the centrality of post-war reconstruction in Soviet policy-making. The colossal destructiveness of the war on the Eastern Front would, it was believed, leave the economic infrastructure in the most productive areas of the USSR in ruins. ${ }^{10}$ The British Ministry of Economic Warfare and the American Board of Economic Warfare pooled much of their information on the Soviet economic situation, but they never reached agreement on how long reconstruction would take. ${ }^{11}$ Estimates varied between five and twenty years, but all were agreed that making good the damage of the war would be a major aim of Stalin's policy. ${ }^{12}$ British and Americans saw this to be an important factor in his foreign policy, but they parted company on exactly what use to make of this.

The chief American interest in the reconstruction question revolved around the provision of assistance in the form of credits and trading arrangements. Soviet needs in this area were seen as providing an opportunity to influence their policy towards cooperation along the lines the United States desired. There was a range of views as to how this might be exploited, often depending on how much it was felt the Soviet economy would be actually dependant on outside aid. Two main schools of thought are evident with regard to the implications of Soviet reconstruction

\footnotetext{
${ }^{8}$ Reynolds, World War to Cold War, 245-6.

${ }^{9}$ Harriman to Hopkins and Stettinius 9 Nov., Harriman to Stettinius 16 Nov. 1943 FRUS1943:III, 7869

${ }^{10}$ Report on the Soviet Economy 20 March 1942 FRUS1942:III, 425-6; Ministry of Economic Warfare Enemy Branch Reports, 'Economic Effects of the Russian Advance During the Period July-Oct. 1943' 20 Oct. 1943 FO371/36951/N6487 and 'Report on the Economic Resources of Eastern Russia' 28 July 1944 FO371/43329/N4864.

${ }^{11}$ Ministry of Economic Warfare, Enemy Branch Reports 4 and 8, Sept.-Oct. 1942, FO837/32.

12 Berle speech 4 April 1943 State Department papers R[ecord] G[roup] 59 740.0011/28963, US National Archives, College Park, Maryland; Commissar for Trade Anastas Mikoyan said the destruction would take fifteen years to make good, Harriman to Hull 14 Feb. 1944 FRUS1944:IV, 1054; reporters visiting Kharkov reckoned twenty, Standley to Hull 15 March 1943 FRUS1943:III, 512; Harriman to Hull 24 July 1944 FRUS1944:IV, 980; Churchill to Attlee 1 Feb. 1943 FO954/22A; British Joint Intelligence Committee paper JIC(44)105(O) 'Soviet Foreign Policy After the War' 20 March 1944 CAB[inet papers, UK National Archives] 81/121: Warren F. Kimball, Forged in War. Roosevelt, Churchill and the Second World War (New York, 1997), 251.
} 
needs. Harriman saw reconstruction loans and credits could be used as bargaining counters in negotiations, achieving specific concessions in return, while Roosevelt, Harry Hopkins and Treasury Secretary Henry Morgenthau saw the provision of credit as a means to improve the overall environment in which relations would be conducted. ${ }^{13}$ Even if it was just one of a number of options open to the Soviet leadership, it was still felt that the hopes for US economic assistance and access to American technology and resources might be a powerful incentive for cooperation. ${ }^{14}$ Interestingly, Ivan Maisky when considering the issue of postwar cooperation in his position as a deputy commissar for foreign affairs, considered the reconstruction problem to be a good reason for keeping good relations with the British and Americans, while also expressing the orthodox Soviet opinion that the capitalists would themselves need to trade with the USSR after the war. ${ }^{15}$

Following up on Harriman's conjecture, Elbridge Durbrow, in charge of East European affairs in the State Department, argued that Soviet fear of their own weakness was the best lever to induce them to drop what was characterised in the Department as their 'unilateralist' policy. Durbrow thought the Soviet leaders probably realised that cooperation with the US was the one policy that could assure wholehearted western aid to repair the devastation of their country, and he concluded from this that the US should follow a policy combining friendliness and firmness - essentially a mixture of sticks and carrots to persuade the Soviets it was in their interest to 'join the family of nations as a fully-fledged member.' Through this method, it might be possible to convince them to drop what Durbrow described as 'the odious aspects of their "backdoor" methods of interference in other countries.'

Although it clearly squared with a major Soviet material interest, however, Durbrow felt that this goal would still be difficult to attain. State Department Soviet experts remained sceptical about developments in the USSR, especially in regard to religion and the abolition of the Comintern, although as Eduard Mark pointed out, there had been since before the war a readiness among some officials in the Department and elsewhere in Washington to see Stalin's Soviet Union as impelled by nationalistic rather than revolutionary motivations. ${ }^{16}$ It is important to note, however, that the use of the term 'firm' did not imply non-cooperation, and should not be taken to presage proto-Cold War attitudes. There is certainly an element of 'tough bargaining' here, but also a sense that the Soviet reconstruction problem, if managed effectively, could be used to lever the USSR into being cooperative with the allies and conforming to American models of inter-state behaviour. ${ }^{17}$

${ }^{13}$ Randall B. Woods, Changing of the Guard. Anglo-American Relations, 1941-1946 (Chapel Hill, NC, 1990), 151.

${ }^{14}$ George C. Herring, Aid to Russia 1941-1946: Strategy, Diplomacy and the Origins of the Cold War (New York, 1973), 112-42; Mark Harrison, 'The Soviet Economy and Relations with the United States and Britain, 1941-45', in Ann Lane and Howard Temperley eds, The Rise and Fall of the Grand Alliance (London, 1995), 74. Averell Harriman had done good business in the USSR during the 1920 s, principally in minerals, and he and other American businessmen were not prejudiced against trade with the Soviets. Eduard Mark, 'October or Thermidor? Interpretations of Stalinism and the Perception of Soviet Foreign Policy in the United States, 1927-47'American Historical Review 94 (1989), 949; Warren Kimball, 'The Ghost in the Attic: The Soviet Union as a Factor in Anglo-American Wartime Planning for Postwar Germany, 1943-1945' in A. Funk ed., Politics and Strategy in the Second World War (Lawrence, KS, 1975), 107.

${ }^{15}$ Maxim Litvinov made a similar point: V. O. Pechatnov, 'The Big Three After World War II: New Documents on Soviet Thinking About Post-War Relations With the United States and Great Britain', Cold War International History Project Working Paper 13 (1995), 4, 12-13

${ }^{16}$ Mark, 'October or Thermidor?, 945-6; Durbrow interview, 1973, oral history collection, Truman Library www.trumanlibrary.org/oralhist/durbrow.htm. On the Comintern: Standley to Hull 23.5.43 FRUS1943:III 531-2, Winant to Hull 24 May 1943 FRUS1943:III, 532; on religion, Durbrow memo 29 Sept. 1943, FRUS1943:III, 860-3; Harriman to Hull 21 Jan. 1944 FRUS1944:III, 1232. For religion in the USSR during the war, see Steven Merritt Miner, Stalin's Holy War. Religion, Nationalism, and Alliance Politics, 1941-1945 (Chapel Hill, NC, 2003), 76-96.

${ }^{17}$ Durbrow memo 'Certain Aspects of Present Soviet Policy' 3 Feb., Harriman to Hopkins 13 Feb., Harriman to Hull 13 March 1944 FRUS1944:IV, 816, 1054, 951. 
Harriman and some in the State Department and other parts of the Washington bureaucracy believed the changes in the USSR had potential significance, and in particular linked them with the idea that there were different schools of opinion within the Soviet leadership regarding the internal application of ideology and relations with the allies. This view derived from the observation that at times Stalin was much more cooperative in his demeanour than other leading figures and rank-and file officials. Harriman had observed this in October 1941 at the Moscow supply conference and it was to be one of his consistent themes. There was speculation that there were a number of power centres within the Soviet ruling elite, and moreover that those in the Politburo and the Red Army had sufficient independence to put forward their own views and to be able to argue with Stalin. Two schools of thought were postulated. One was cooperative, believing that Soviet interests were best served by association with the West to control German power. The other had favoured the German option before the war. ${ }^{18}$ Its members were said to be die-hard members of the Communist Party and the officials of the NKVD, and possibly also the marshals of the army in the field. They were held deeply to distrust foreigners, and to believe the USSR should follow a kind of 'Fortress Russia' policy, dependent on its own resources, behind a defensive glacis of subservient bordering states. The key question was where Stalin stood in this policy debate. While some saw him as sharing many of the attitudes of the isolationist group, the common assumption was that he was in the cooperative school, and shared this outlook with many of the managerial types seen as having come to the fore as a result of the policy of "socialism in one country. ${ }^{19}$ It was concluded, moreover, that Stalin was essentially a realist, who, though suspicious and sensitive, understood the realities of power. Security was his main concern. He needed to be educated, however, to understand that the security and economic benefits that would result from cooperation with the United States were conditional on the USSR dropping its tendency to defy the norms of international behaviour and ceasing to operate unilaterally. ${ }^{20}$

\section{British views of Soviet policy}

When British viewpoints are examined for the same period, from Teheran to the Stettinius mission, at first sight is difficult to understand why Stettinius emphasised their difference from those of the United States. The leading officials in the Foreign Office (FO), Permanent Under-Secretary Sir Alexander Cadogan and Deputy Under-Secretary Sir Orme Sargent recognised that if cooperative relations were not maintained with the USSR after the war, the situation would be grim. Cadogan was reluctant to expect much from the Soviets: Sargent, who occupied a pivotal role conveying the views of the regional departments to the Foreign Secretary, showed more readiness to believe that skilful diplomacy could achieve that result. ${ }^{21}$ FO officials tended to see the way to engender long-term cooperation to involve 'firmness', 'frankness' and 'fairness', the same words used by Harriman and the

${ }^{18}$ Harriman comments to Bruce Lockhart, Director of British Political Warfare Executive, Lockhart diary 11 Feb. 1943, K. Young ed., The Diaries of Sir Robert Bruce Lockhart, 1939-45 (London, 1980); Standley to Hull 10 May, Davies to Roosevelt 29 May 1943 FRUS1943:III, 509, 658; Harriman to Hull 28 Jan. 1944 RG59 740.0011/2105.

19 Welles memorandum 12 Aug. 1943 FRUS1943:III, 684; Harriman to Hull 6 Feb. 1944 FRUS1944:IV, 822. See Pechatnov, 'Big Three After World War II,' 24, for a suggestion that this idea of an internal Soviet foreign policy debate may not have been as far-fetched as has often been implied.

${ }^{20}$ Larry Bland, 'Averell Harriman, the Russians and the Origins of the Cold War in Europe, 1943-45', Australian Journal of Politics and History 23 (1977), 408-09; Law minute of meeting with Roosevelt 22 Dec. 1944 FO371/44595/AN155.

${ }^{21}$ Neither of these important officials has been the subject of an authoritative biography. Their views on the USSR have to be gleaned from FO minutes and Cadogan's diary in the Churchill Archives. For character sketches by a colleague, see Lord Gladwyn, The Memoirs of Lord Gladwyn (London, 1972), 70,73 
DEA. There was much common ground in the way that the two bureaucracies had come to view their Soviet ally. The State Department and FO and the two embassies made some similar basic assumptions. They both used ethnic stereotypes to characterize the Soviets, regarding them as essentially 'oriental', which was taken to mean that they would regard concessions and excessive praise as signs of weakness, and would be encouraged to press for more. They respected a bargain, particularly a hard one. These assumptions were the basis for the axiom of 'firmness with frankness'; the stating of interests clearly, dispensing with sentiment, but at the same time consulting the Soviets and in the process 'civilizing' them so that as Durbrow put it, they would join the 'family of nations'. ${ }^{22}$ By 'firmness', the professional diplomatists in Washington and London thus did not mean a Cold War-style confrontation, but held that since the Soviets were 'orientals' and potential bullies, they would respect those who stood up for their interests. However, as with other aspects of the Anglo-American partnership, similar words masked differences in meaning: cultural differences, geo-political concerns and, to a degree, ideology, produced divergent concepts and policies.

The British placed Soviet reconstruction needs at the centre of their analyses of the prospects of cooperation with the Soviets as did the Americans, but they approached the issue rather differently. In 1943, they had hopes of being able to provide such aid, which would be an economic benefit to Britain as well as help build up a positive post-war relationship with the Soviets. Investigations with companies which had traded with the USSR before the war established that they were honest in business and adhered to contractual arrangements. ${ }^{23}$ By 1944 it was becoming doubtful that Britain would have much in the way of resources to offer to the Soviets in the crucial immediate post-war period. However, trade for British businesses was only a minor element of FO interest in the issue. Far more important was the conclusion that the FO Northern Department and the embassy in Moscow drew from their assumption of the immensity of Soviet reconstruction requirements. Where Durbrow saw a need to actively use the issue for leverage, the British concluded that the issue would drive Soviet behaviour without specific encouragement from the allies. In the Northern Department, the assumption of Soviet reconstruction needs underpinned the conclusion that the Soviets would cooperate with the allies. They would do this not out of sentiment, nor because they had changed their ideology, but from over-riding and urgent material interest. The FO drew a firmer conclusion on this than the Americans because they saw the motivation working differently. It was not so much that the Soviets hoped for credits, but because reconstruction, which the FO believed was likely to be based as much as possible on the established Soviet policy of self-sufficiency, would mean they needed a long period of peace and stability. This could best, and most cheaply, be achieved by cooperation with the allies, so long as they were convinced the allies were sincere in cooperating with them and would help them to hold down Germany. This strong assumption about the reconstruction needs of the USSR, independent of specific allied actions, produced a series of formulations about Soviet cooperation in 1943-44 that can be seen as optimistic, but which officials regarded as realistic. It followed that the main way the allies could ensure cooperation would not be credits or trade, but mutual recognition of security interests. It was this conclusion regarding the reconstruction question that was the basis for what is often described as 'pragmatism' on the part of the FO. ${ }^{24}$

To be sure, the FO's Soviet specialists were markedly more optimistic than those in the American government. The Northern Department contained some officials convinced of Stalin's interest in long-term cooperation and the limited

\footnotetext{
${ }^{22}$ Durbrow memo 3 Feb. 1944 FRUS1944:IV, 816.

${ }^{23}$ Eden to Dalton 30 July 1943 FO371/36983/N4251.

${ }^{24}$ FO paper 'Probable Post-War Tendencies in Soviet Foreign Policy as Affecting British Interests' 19 April 1944 FO371/43335/N1008; Warner minutes 29 July 1944 FO371/40741A/U6792; FO Cabinet paper WP(44)436 'Soviet Policy in Europe' 9 Aug. 1944 CAB66/53.
} 
nature of his ambitions. The main contributor of detailed analysis was Geoffrey Wilson, a temporary official of Quaker background, who had been personal secretary to the left-wing MP Sir Stafford Cripps on a visit to the USSR in 1940. The Head of the Department, Christopher Warner, a professional diplomat, but no expert on the Soviet Union, was a little more cautious, but susceptible to Wilson's line of argument. Generally, the Northern Department and Ambassador Sir Archibald Clark Kerr's embassy in Moscow had come to believe that a post-war alliance with the Soviet Union, at least while Stalin was alive, was possible and desirable. The USSR, they believed, had been transformed by Stalin and his policy of 'socialism in one country' into a nation-state rather than a 'revolutionary notion.' Changes in Soviet society of a conservative nature since Stalin's rise to power had been accelerated by war. They were very aware that this state had expansionist tendencies, akin to those that had brought Russia into conflict with Britain for 125 years, but projecting forward from these internal developments, they appeared to be of a traditional kind that the FO felt competent to understand and deal with. Soviet interests, the guiding principle for the realist Stalin, appeared to point in the direction of the kind of cooperation the British also desired: limited in many ways (not involving exchange of cryptographical or atomic secrets, for example), but real nonetheless. They were more optimistic in regard to religion and the abolition of the Comintern than their counterparts in the State Department. ${ }^{25}$ The embassy, however, was inclined to be sceptical about the two schools thesis, while prepared to accept that Stalin was more friendly than Molotov. Within the embassy, the ambassador's second-in-command, Sir John Balfour, was closer to the Americans than Clark Kerr was: the ambassador disliked the Moscow diplomatic corps, which he nicknamed the 'anti-Soviet sewing bee.' He tried to avoid the closed, gossipy and often bitter world of the diplomats, and make human contact with his Soviet counterparts - interestingly, the only one with whom he succeeded seems to have been Stalin himself. While, therefore, Balfour was on close terms with George Kennan, his opposite number at the US embassy, Clark Kerr worked well enough with Harriman, but they did not spend a lot of time sharing their insights into the USSR. ${ }^{26}$

By 1944, the FO believed the Soviets would be dominant in Eastern Europe, and that a British-coordinated Western Europe would be linked to this by the Anglo-Soviet Alliance. By this means would Germany be restrained, even if the Americans withdrew from Europe. They believed this aim was capable of achievement, though diplomacy with the suspicious Soviets was difficult. It would require the skilled blend of firmness with friendly frankness that the FO believed they themselves possessed. ${ }^{27}$ The FO certainly shared the American preference for a policy of 'firmness'. However, for them it was part of a different spectrum of possible policies: it represented a middle course between a 'soft' policy of concessions, even appeasement, and a 'hard' policy of refusal of any collaborative action except on terms of strict and symmetrical reciprocity, with the default position of no contact at all. The key to understanding the FO's approach was that firmness was always to be associated with frankness, which centred on an open exchange of views, stating one's interests without fear that doing so would stymie cooperation. The difficulty was finding an appropriately calibrated policy that did not feed Soviet suspicions.

25 Winant to Hull 24 May 1943 FRUS1943:III 532-3; Warner minute 19 May 1943 FO371/36961/N6710; Clark Kerr to FO 30 Sept. 1943 FO371/36963/N5745; Martin H. Folly, Churchill, Whitehall and the Soviet Union (London, 2000), 54-75.

${ }^{26}$ Clark Kerr to Warner 30 Aug. 1942 FO800/300, and 30 July 1943 FO800/301, Frank Costigliola, 'Archibald Clark Kerr, Averell Harriman, and the fate of the wartime alliance', Journal of Transatlantic Studies 9 (2011), 83-97.

${ }^{27}$ FO paper 'Probable Post-War Tendencies' 19 April 1944 FO371/43335/N1008. 


\section{Churchill and Eden}

Prime Minister Churchill was not in sympathy with all elements of the FO analysis. He was not yet, however, the Cold Warrior of later years. From the start of the war, he had tended to see Soviet policy as driven by interests not ideology. ${ }^{28}$ In January 1944, Churchill noted that he was impressed by Stalin and the 'deep-seated changes' in the USSR. ${ }^{29}$ However, he had attempted a style of handling Stalin, by focusing on military issues and eschewing political ones, which developments early in 1944 revealed to be inadequate. Although the War Cabinet endorsed the future potential for cooperation with the USSR in January 1944, the cooperative glow of Teheran faded quickly for both Churchill and Foreign Secretary Anthony Eden. ${ }^{30}$ Their response was inclined to be emotional. This became evident when Pravda published a story in January 1944 that the British had been attempting to negotiate a separate peace with Germans in Romania. The story cut Churchill to the quick. ${ }^{31}$ It was followed in the next two months by a failure to make any progress in bringing together the London Polish Government-in-exile and the Soviets. The Poles would not accept the loss of eastern territory to the USSR, which had been agreed in their absence at Teheran, and the Soviets refused to restore relations with the Poles, which they had severed in April 1943 over the issue of the Katyn massacre. While they had pressed the Poles to agree on the frontier, Churchill and Eden began to see sinister motivations in the Soviet demands for changes in the personnel of the Polish Government as a precondition for opening territorial discussions. ${ }^{32}$

Eden expressed doubts about the Soviets as counterpoints to the optimistic assertions from the Northern Department, though his tendency when faced with Churchillian ire was to attempt to mitigate its force. At one point in February 1944 he noted the persistence of suspicions of the Soviet Union in certain sections of the Conservative party (his own party) with the implication that he did not share them and indeed that they were somewhat antediluvian. ${ }^{33}$ Thus, just prior to Stettinius's visit, he is to be found asserting to Churchill that actually the Soviets had not done much wrong recently - implying that odd incidents, and the tone of comments in the Soviet press, should not be taken too seriously - and also implying that the Polish issue should be treated as sui generis.

The occasion for this statement by Eden was a comment by US Secretary of State Cordell Hull to Lord Halifax, the British ambassador at Washington, on 28 March. Hull was one of those who believed the Soviets' default position was unilateralism, and was sensitive to signs that the turn to cooperation was superficial. He had been absent from Teheran, where Roosevelt embarked on his project to form a bilateral relationship with Stalin, and at the end of March 1944 he pressed for the formulation of a joint Anglo-American approach, assuming that the British shared his apprehensions. Hull was responding to the strongly expressed misgivings within his department, from Durbrow and others, but also to American press speculation that the USSR was failing to follow a multilateral, consultative policy in its relations with Poland. ${ }^{34}$

${ }^{28}$ Martin Gilbert, Road to Victory (London, 1986), 323, 471, 492, 501. When he gave his famous 'riddle wrapped in a mystery inside an enigma' comment about Soviet policy, he went on to describe the key to it as Soviet national interest, BBC radio broadcast 1 October 1939.

${ }^{29}$ Churchill to Eden 16 Jan. 1944 PREM3/399/6.

${ }^{30} \mathrm{WM}(44) 11$ th mtg Confidential Annexe (CA) 25 Jan. 1944 CAB65/45.

${ }^{31}$ Churchill to Stalin 24 Jan., Eden minute 28 Jan. 1944 PREM3/396/11; cf Hull to Harriman 15 Jan. 1944 FRUS1944:III, 1229. Warner thought that the Pravda story had been a retort to a Daily Express report that a British mission to Romania had been carrying a proposed Soviet-German treaty. He warned against assuming the Soviets had changed policy simply because of a few adverse press articles, Warner minute 25 Jan. 1944 FO371/43304/N776.

${ }^{32}$ Churchill to Stalin 28 Jan. 1944 FO371/39387/C1067.

${ }^{33}$ Eden minute 18 Feb. 1944 FO371/43304/N937; Eden to Churchill 13 March 1944 PREM4/18/3.

${ }^{34}$ Durbrow memo 3 Feb., Harriman to Hull 13 March 1944 FRUS1944:IV, 816, 1054, 951; Hull conversation with de Morgenstierne 24 March 1944 RG59 761.00/369. 
Hull suggested to Halifax that the time had come for a plain-speaking AngloAmerican approach to Stalin, pointing out to him the consequences if he continued taking one-sided action. Halifax noted

$\mathrm{He}$ was clearly perturbed at the criticism of the United States Government over the whole field of foreign policy arising from the general feeling that the tide of Moscow and Tehran had ebbed.

$\mathrm{He}$ attributed this in the main to the one-sided behaviour of Russia...

Only thing approaching a remedy that he could suggest for this was somehow or other to establish closer relations between the Prime Minister, the President and Stalin. ${ }^{35}$

Hull's emphasis on working together appealed to Churchill, and he suggested to Eden that an Anglo-American approach be made, while simultaneously lapsing into 'a moody silence' in diplomatic contacts more generally. He proposed to follow that principle in his own correspondence. ${ }^{36}$

Like Hull, the British leaders were concerned about Soviet 'unilateral' actions, though the policies that gave offence to them were not always the same ones that aroused Hull's misgivings. The Soviets had acted unilaterally in Italy in recognising Marshal Badoglio as the head of the Italian government, ahead of the British and Americans, and the Italian communists were being cooperative as members of an expanded government. This excited Eden's suspicions in particular: even though the regime in Italy could not have existed without Anglo-American sanction, it was the mode of Soviet action that rang alarm bells. It seemed of a piece with the Soviet press giving exaggerated accounts of the prowess of the Greek communist resistance, EAM/ELAS. Eden was showing some signs of exhaustion at the time - indeed when it was proposed that Stettinius come over during the Easter parliamentary recess he responded petulantly, declaring himself tired and in need of a break. ${ }^{37} \mathrm{He}$ expressed deep pessimism about Soviet aims the dominance of Eastern Europe, the Mediterranean and the 'communizing of much that remains' - in internal FO papers. ${ }^{38}$

However, when Churchill voiced his own misgivings, Eden attempted to argue him out of the idea of a showdown, adopting as his own the less pessimistic views of his officials, and commenting 'In point of fact, exasperating as recent Russian behaviour has been, I feel we ought not to jump to the conclusion that they have decided to go back on the policy of co-operation. There have been not a few cases on the credit side.' Eden asserted that the Soviets were not only not being uncooperative, but that Britain had boosted EAM and the Yugoslav partisans before the Soviets had. Churchill did not press the showdown idea. ${ }^{39}$ Conversely, when the Soviets asked for an air base in south Italy, Eden saw this as sinister, and Churchill regarded it very calmly. It would be wrong, therefore to pick out Churchill's eminently quotable minutes and see them as indications of consistent policy rather than spontaneous expressions of frustration that were set aside on

${ }^{35}$ Halifax to FO 28 March 1944 FO371/43304/N1908.

${ }^{36}$ Churchill to Eden 1 April 1944 FO371/43304/N2128. Churchill had just received a curt message from Stalin on the Polish issue, Vladimir Pechatnov, 'How Stalin and Molotov Wrote Messages to Churchill. Following Stalin's Archives' Russia in Global Affairs 7 (2009), 170.

${ }^{37}$ Eden scribbled note on Halifax to Eden 10 March, Eden to Halifax 20 March 1944: 'Everybody here is very tired, especially your humble servant, and we must get a few days at Easter if we are to remain alive' FO371/38578/AN1196.

${ }^{38}$ Eden notes on Wilson and Sargent minutes 3 April 1944 FO371/43304/N1908.

${ }^{39}$ Eden to Churchill 5 April 1944. Sargent noted on 19 April, 'Sufficient time has now elapsed to allow tempers to calm. ... I am sure it would be best in these circumstances to let sleeping dogs lie.' Warner thought Hull would not pursue the matter if no further cases of Soviet lack of cooperation attracted the attention of the newspapers, minute 7 April 1944 FO371/43304/N2128. 
reflection. ${ }^{40}$ As these exchanges took place, FO officials expressed regret at the emotional outbursts and swings between euphoria and hostility. The theme of Warner and others was that calm, unexcited consistency, plus patience and firmness, were needed. Appeasement, Warner had written in January, had had its time - but at the same time he and his officials put forward detailed papers on the favourable prospects of cooperation with the Soviets and pressed that what was crucial was proper handling of them. ${ }^{41}$ Sargent had responded to Hull's remarks by arguing that cooperation had not broken down: the objectionable aspects of Soviet behaviour were because of ignorance and clumsiness and the fact that their officials had been indoctrinated for twenty years not to cooperate. The implication was that the British were better attuned to understanding Soviet policy than the Americans. While the Americans might feel it was an option, Sargent argued that for Britain it would be disastrous to abandon cooperation with the USSR unless forced to. Britain should protest about unacceptable behaviour, but a joint AngloAmerican front should be avoided as it would provoke adverse Soviet reactions. ${ }^{42}$

This was the atmosphere that Stettinius's mission picked up while in London. The main items on Stettinius's agenda were post-war international organization and the future of British colonialism. More specific matters included limits on Spanish wolfram exports to Germany. Stettinius had lunch with Churchill, at which he was impressed by the extraordinary amount of port and brandy the prime minister consumed, had talks with John Anderson, the Chancellor of the Exchequer, and stayed in the country with Eden. ${ }^{43}$ This was Eden's way of getting his rest and not delivering too strong a snub to the American. He also met the King of Greece, and the Prime Minister of Poland, and much of his time was spent visiting American army units preparing for D-Day, such as the 101st Airborne - a schedule cooked up by the FO to get him out of Eden's hair. The main topic the British wanted to talk about was the non-functioning of the European Advisory Commission (EAC), wherein the American representative had been less forthcoming than the Soviet one.

The British anticipated that Stettinius would bring up Soviet uncooperativeness and follow up Hull's comments to Halifax, but Hull had no desire to use Stettinius as an intermediary, and he did not address the matter directly. ${ }^{44}$ This vital topic seems only to have been touched upon directly with the British once, though Stettinius did discuss Soviet actions with some of the exile governments. The one occasion was a conversation between Warner and $\mathrm{H}$. Freeman Matthews, Deputy Director of the Office of European Affairs, on 17 April. It was merely a sharing of views rather than a discussion of tactics, let alone an attempt at co-ordinating them or even drawing joint tactical conclusions from the viewpoints they shared. Matthews noted in his account of the conversation that there was no great divergence of views on the USSR. Matthews explained the difficulties they had with American public opinion, and the disillusionment produced by the Polish situation and the Soviet recognition of Badoglio. He

${ }^{40}$ Compare Churchill's comments at War Cabinet 11 May WM(44)63rd mtg CA with those of 11 April WM(44)47th mtg CA CAB65/46. David Reynolds describes Churchill's attitude to the USSR at this time as 'mercurial,' Reynolds, From World War to Cold War, 131.

${ }^{41}$ Warner to Clark Kerr 25 Jan. 1944 FO800/302; FO paper 'Probable Post-War Tendencies' 19 April 1944 FO371/43335/N1008.

${ }^{42}$ Sargent minute 3 April 1944 FO371/43304/N1908.

${ }^{43}$ Thomas R. Campbell and George C. Herring, The Diaries of Edward R. Stettinius, Jr., 1943-1946 (New York, 1975) entries for 9 April, 10 April, 12 April, 19 April, 24 April 1944. Stettinius also met Sargent to discuss Bulgaria, conversation 18 April 1944 RG59 740.0011 Stettinius Mission/141; Stettinius Mission report FRUS1944:III, 304-5. Michael M. Boll, Cold War in the Balkans: American Foreign Policy and the Emergence of Communist Bulgaria, 1943-1947 (Lexington, KY, 1984), 32. Cordell Hull, The Memoirs of Cordell Hull (New York, 1948) volume 2, 1427-29; Woods, Changing of the Guard, 155.

${ }^{44}$ Warner minute 7 April 1944 FO371/43304/N2128. Hull had complained to Morgenthau that he knew nothing about the aims of Stettinius's mission, J. M. Blum, From the Morgenthau Diaries: Years of War, 1941-1945 (Boston, 1967), 136-7. 
stressed how Hull pressed on Andrei Gromyko, the Soviet ambassador in Washington, the need to work through consultation and mutual agreement rather than unilateral action. Warner and Matthews agreed that the message seemed to be getting through. Warner took Sargent's line that there was a tendency to see every Soviet action as part of a carefully thought-out long term plan, and to attribute deep-lying motives to some minor act. This was inaccurate, Warner said, and overlooked internal political needs and purposes in the USSR. This reflected the frustration of his department with what they saw as over-excitable reactions by those who did not pay attention to the full picture. Warner believed cooperation with the USSR in the post-war era to be the most important objective of British policy. Given the background of Soviet hostility and suspicion - Matthews noted that Warner did not mention traditional Anglo-Russian rivalry - Warner believed the road 'will be long, slow and painful, but that the chances of ultimate success are pretty good.' Matthews added that Warner seemed to fear that the Americans would be less patient with the Soviets and that relations might deteriorate as a consequence:

He seemed quite relieved when I assured him that the

Secretary is well aware of all the pitfalls and the

slowness with which Russian cooperation and

consultation must necessarily develop and that his

policy is equally one of the utmost patience. ${ }^{45}$

Although Matthews seemed satisfied that there was little divergence in view, in fact, Warner's comments accurately reflected some key viewpoints that were leading the British away from the Americans and would make coordination of policy out of the question. They felt that the behaviour that prompted Hull's fears of unilateralism was mainly caused by Soviet ignorance and clumsiness. There was also a concern that surfaces in a number of comments in the FO, and in the next two months from Churchill and Eden too, that the Americans were less engaged with European problems and more likely to plunge ahead recklessly with policies that would make the situation worse. It is interesting that usually the British are presented as the tougher in 1944, with the Americans (notably the president) following a policy that was far too concessionary, whereas at the time, the British feared the Americans would push relations to a break through impatience. ${ }^{46}$

The Americans, for their part, thought the British were making things difficult for themselves. Stettinius concluded, on the basis of Matthews' talk and passing remarks by Eden and Churchill, that while the British saw continuing cooperation with the USSR to be the keystone of their post-war policy in Europe, there was friction in Anglo-Soviet relations that was not present in SovietAmerican relations. ${ }^{47}$

\section{Divergences become evident}

The opportunity the Stettinius mission offered to coordinate tactics of handling the Soviets soon passed. The exhausted Eden had gone on leave after Stettinius's visit. Churchill took on the role of Foreign Secretary, and allowed himself to be drawn into a fruitless dispute with Molotov. In December 1943, the British had parachuted some officers into Romania to make contact with opposition elements:

45 Matthews memorandum of conversation 17 April 1944 RG59 761.00/4-1744. Warner also emphasised the likely influence of Soviet reconstruction needs and war-weariness on their postwar foreign policy.

${ }^{46}$ Cf David Dilks, 'British Political Aims in Central, Eastern and Southern Europe, 1944' in W. Deakin, E. Barker and J. Chadwick eds, British Political and Military Strategy in Central, Eastern and Southern Europe in 1944 (London, 1988), 23; Robert Garson, 'The Atlantic Alliance, Eastern Europe and the Origins of the Cold War: From Pearl Harbor to Yalta', in H. C. Allen and R. Thompson eds, Contrast and Connection: Bicentennial Essays in Anglo-American History (London, 1976), 299-300.

${ }^{47}$ Report of Stettinius Mission FRUS1944:III, 10. 
they had been captured, but their leader, Colonel Alfred de Chastellain, had been used by Romanian dictator Ion Antonescu to encipher a message which the Soviets regarded as offensive. ${ }^{48}$ In April, the Soviets, whose troops were soon to enter Romania, cast aspersions on British motivations, implying once again that they were dealing with the enemy. The FO suspected that similar suspicions regarding this mission (Operation Autonomous) had been the cause of the Pravda secret peace story in January. Churchill protested British innocence and accused Molotov of having 'got hold of a mare's nest.' Molotov's reply seemed to Churchill to be an attack on his good faith. He replied robustly. While the FO enjoyed Churchill's tough language, they viewed the whole correspondence as regrettable. It called forth, not for the first time, a comment by Eden when he returned from leave that he wished the prime minister would desist from such messages to the Soviets. ${ }^{49}$

Observing this exchange reinforced a sense of superiority in the State Department. On 6 May the DEA noted that it was 'evidence of general mistrust, bad manners and acerbity between two of the major Allies.' Cavendish Cannon of the Southern Europe desk at the DEA remarked that Churchill's language 'impressed me as being dangerously rough and ill-tempered for a minor incident when more important issues require good will on both sides. ${ }^{50}$ Cannon's tone of critical detachment is typical of the way both the Americans and British regarded each other's apparently faltering relations with the USSR.

It is hardly surprising, therefore, that the Americans drew the conclusion that British relations with the Soviets were considerably worse than their own. Where the British suspected the Americans of being short of patience, the Americans felt the British approach more likely to bring confrontation than cooperation. Consequently there was no desire to coordinate policies and thereby tie the Americans into British troubles. No attempt was made on the basis of Stettinius's report to narrow the perceived gap - and soon the changing military situation in the Balkans region made it harder to do so, as the British attempted to apply their 'frankness' approach to handling the issues raised by Soviet advances in Romania and the Americans stuck to their inclination to avoid direct involvement in what they regarded as subsidiary political issues. ${ }^{51}$

In Whitehall, despite Churchill's angry invective, the FO were moving ahead, seeking to build on the keystone concept and operationalise cooperation through working arrangements involving accepting each other's policies in particular areas, in preference to the creation of more consultative machinery. Their experience with the EAC, which they had proposed with high hopes in October 1943, but which had made very slow progress, influenced their preference for more ad hoc bilateral arrangements. The implication of the keystone concept was that there would be de facto west and east European blocs, which would be prevented from being confrontational or exclusive spheres of influence by the over-arching Anglo-Soviet Treaty, the binding element. They now sought to use a pragmatic arrangement concerning Romania as the foundation for a more general principle. ${ }^{52}$

While there had been fractious exchanges over the de Chastellain mission, otherwise, Anglo-Soviet relations over Romania seemed to the FO to be working quite well. They made clear to the Soviets that Britain would follow their lead, and in return the Soviet terms for Romanian surrender seemed moderate and even

${ }^{48}$ Ivan Porter, 'Some Notes on Operation Autonomous: Romania, 1944' in Deakin et al, British Political, 162-79.

49 Clark Kerr to FO 6 May, Molotov to Churchill 10 May 1944 FO371/43999/R7287, Eden to Churchill 15 May FO371/44000/R7830.

${ }^{50}$ Cannon memorandum to Dunn 6 May 1944. Dunn to Hull 10 May 1944 RG59 740-00119/2616.

${ }^{51}$ For Anglo-American differences on policy towards the Balkans, see Geir Lundestad, The American Non-Policy Toward Eastern Europe 1943-47: Universalism in an Area not of Essential Interest to the United States (Tromso and London, 1978); Boll, Cold War in the Balkans; Elisabeth Barker, British Policy in South-East Europe in the Second World War (London, 1976); Garson, 'Atlantic Alliance', 310-15.

${ }^{52}$ Clark Kerr to FO 2 May 1944 FO371/43686/R7102. 
generous. Furthermore, before the de Chastellain issue had blown up with Churchill, Molotov had made a point of stating his own ignorance on the Greek issue and explicitly invited the British to take the lead and provide guidance. ${ }^{53}$ At a time when Churchill was recommending Clark Kerr be brought home for a time, and pressing for consideration of a showdown over communist intrigues in Italy, Yugoslavia and Greece, Eden and the FO Southern Department embarked on a different approach to getting better Soviet behaviour. ${ }^{54}$ This initiative has often been discussed, though almost always simply as a prelude to the Churchill-Stalin 'percentages' discussion in October 1944. ${ }^{55}$ It should also be viewed as an attempt to put into practice the preferred FO way of handling the Soviets, through frank discussion of interests: a method which Churchill now found to have some attractions. He preferred to coordinate with the Americans, but if that was not possible, he showed as the issue unfolded that he was prepared to proceed anyway. In a conversation with Soviet ambassador Fyodor Gusev on 5 May, Eden suggested casually that an arrangement like that over Romania might also be profitably followed over Greece. Gusev received the suggestion favourably and on 18 May reported that his government accepted the idea that they take the lead in Romania and Britain take the lead in Greece. They asked, however, what American views were. It was the Soviets who thus showed most concern for the tripartite aspect of cooperation at this point. ${ }^{56}$

Having vented his feelings in internal minutes (and over dinner with his friend Harriman), Churchill then proved easy to convince of the possibility of managing Soviet tendencies by agreements based on the recognition of mutual interest. ${ }^{57}$ This kind of arrangement was in effect what 'firmness and frankness' meant to the British, though such bilateral and specific arrangements were a long way from what the Americans conceived of as the proper form for cooperation. Thus it was that while Churchill adopted with zeal the division of responsibility that Eden and Gusev had discussed, the issue came to demonstrate the gulf between British and American views of how to handle cooperation with the Soviet Union. Although it was ostensibly for ease of wartime collaboration, the prime British aim in May was clearly political, and with long-term goals. ${ }^{58}$ Halifax was told the idea of the Soviets 'taking the lead' in Romania and the British doing the same in Greece was a useful device for heading off divergence in the Balkans of which disquieting signs were emerging. Since they were already supporting Soviet policy in Romania, the FO meant divergence over Greece, and the urgency in the issue was supplied not principally by the advance of the Red Army, but by the recent mutiny of Greek forces in Egypt and the need to bring all Greek parties into line behind the Papandreou government. ${ }^{59}$ It was not a matter of spheres of influence, Halifax was told, nor was the intention to exclude the US. ${ }^{60}$ As with the later 'percentages' discussions, it was principally a statement of British interests, to

${ }^{53}$ Molotov to Churchill 22 April, Clark Kerr to FO 23 April 1944 FO371/43686/R6642, R6530, R6672.

${ }^{54}$ Churchill to Eden 4 May 1944 (2 minutes) FO371/43636/R7380. Southern Department brief 4 May 1944 FO371/43686/R7102; Eden conversation with Gusev 5 May 1944 FO371/44000/R7214.

${ }^{55}$ Elisabeth Barker 'Problems of the Alliance: Misconceptions and Misunderstandings' in Deakin et al, British Political, 48-52; Warren Kimball, 'Naked Reverse Right: Roosevelt, Churchill and Eastern Europe from Tolstoy to Yalta - and a Little Beyond', Diplomatic History 9 1985, 3.

${ }^{56}$ Eden conversation with Gusev 18 May 1944 FO371/43636/R7903.

${ }^{57}$ Eden to Churchill 9 May 1944 FO371/43636/R7380; Memorandum of conversations in London 2-5 May 1944 Harriman papers box 172, Library of Congress.

${ }^{58}$ Sargent to Campbell 8 June, Laskey minute 20 June 1944 FO371/43646/R8988. The FO claimed Eden had no intention of proposing a formal arrangement to Gusev, and that it was the Soviets who made the idea more formal. This was disingenuous: the FO clearly saw it as an arrangement for each to support the other in the countries in question.

59 Boll, Cold War in the Balkans, 36. The mutiny was suppressed by the British. In May, the communists agreed to cooperate with Papandreou in the Lebanon agreement, and EAM received 6 places out of 24 in the government of national unity.

${ }^{60}$ FO to Halifax 25 May 1944 FO371/43636/R7903. 
provide a frank basis for realistic cooperation. ${ }^{61}$ It would also hopefully avoid a repetition of the kind of tetchy exhange Churchill and Molotov in which had recently indulged.

The long-term aspect was immediately picked up in the State Department, where the response was firm opposition to anything that implied exclusive zones of political control. ${ }^{62}$ The Americans were also clearly affronted that the British had gone to the Soviets first, and this feeling was aggravated when the FO clumsily tried to claim that the Soviets were the ones who had brought the subject up. The North American department of the FO saw the American point of view and pressed that the habit must be acquired of consulting them before taking action. The problem then was that the Soviets would always be approached with an apparent piece of Anglo-American 'ganging-up' ${ }^{63}$ The preferred American solution was for all such discussion to take place in 3-power committees. Churchill found this stultifying and the FO, after the EAC experience, had come to prefer bilateral arrangements. Churchill wired to Halifax, 'There is no spheres of influence [sic]. We shall all have to act together, but someone must be playing the hand... No fate could be worse for any country than to be subjected in these times to decisions reached by triangular or quadrangular telegraphing. ${ }^{, 64}$

Roosevelt, echoing the State Department's opinion, told Churchill that the proposal would result in the persistence of differences between Britain and the USSR, not their resolution. The Balkans would become divided into spheres of influence. ${ }^{65}$ The American response became confused when Roosevelt, with Hull out of town, changed his mind in the face of a direct appeal from Churchill. ${ }^{66}$ Roosevelt assented to a three-month trial period, though the State Department's continued opposition was so obvious that the Soviets picked it up and, although it fitted with their objectives, themselves backed away for a while from the arrangement because of their own concern to maintain the alliance. ${ }^{67}$ While

${ }^{61}$ The 'percentages' offer Churchill made to Stalin in Moscow in October is usually seen as an effort to agree spheres of influence. It was also an attempt to state a degree of British interest in states like Bulgaria and Hungary. It never amounted to a formal agreement and the Soviet records make little of it, Robert Garson, 'Churchill's "Spheres of Influence”: Rumania and Bulgaria', Survey, 24 (1979), 145, 151; Geoffrey Roberts, 'Ideology, Calculation, and Improvisation: Spheres of Influence and Soviet Foreign Policy, 1939-1945' Review of International Studies 25 (1999), 668-90; Albert Resis. 'The Churchill-Stalin Secret "Percentages" Agreement on the Balkans, Moscow, October 1944', American Historical Review 83 (1978), 368-87; O. A. Rzheshevksii, Stalin i Cherchill (Moscow, 2004), 418-439.

${ }^{62}$ State Department memorandum 12 June 1944 FRUS1944:V, 119-20.

${ }^{63}$ Eden's private secretary Oliver Harvey recorded Eden's frustration at the need to keep consulting with the Americans, diary 15 July 1944, Harvey papers, British Library Manuscript Collection, London.

${ }^{64}$ Stettinius comments to Halifax 7 June, Butler minute 10 June, 1944, Churchill to Halifax 8 June FO371/43646/R8988.

${ }^{65}$ Roosevelt to Churchill 55710 June 1944 W. Kimball ed., Churchill and Roosevelt: The Complete Correspondence vol 3 (Princeton, 1984), 177. Roosevelt recommended the establishment of consultative machinery instead. Eden noted on Roosevelt's message, 'This is outcome of PM "butting in". What do we do now?' FO371/43646/R9293. As it turned out, Roosevelt was more amenable to persuasion by Churchill than the State Department was by the FO - and Eden himself had agreed to the PM's intervention, and had drafted his initial message to Roosevelt, Eden to Churchill 30 May 1944 FO371/43687/R8543.

${ }^{66}$ Churchill to Roosevelt 70011 June 1944, Roosevelt to Churchill 56013 June 1944, Halifax to FO 15 June 1944, Sargent to Leeper 26 June 1944 FO371/43646/R9472, R9514. It was feared that the State Department would instruct its ambassador to the Greek government to take a lukewarm attitude to the arrangement. Hull was unhappy to discover what Roosevelt had done, Hull to Roosevelt 29 June 1944, Roosevelt to Hull 30 June 1944, Franklin D. Roosevelt Library, Map Room Box 164; Boll, Cold War in the Balkans, 37.

${ }^{67}$ Gusev to Eden 30 June 1944 FO371/43636/R10483. Molotov denied the existence of any arrangement, only for deputy commissar for foreign affairs Andrei Vyshinsky later in September to say there was one, Barker, British Policy, 144. Soviet policy may well have looked to balance the US and Britain against each other, but was also based in 1944 on the continuance of a grand alliance, rather than unilateralism. A sphere of influence was seen as not incompatible with that: a belief that would have been encouraged by the British proposal, A. Filitov, 'The Soviet Union and the Grand 
Churchill ascribed this outcome to what he called 'the pedantic interference of the US,' Eden blamed Churchill's direct approach to Roosevelt for imperilling the FO's hard work. ${ }^{68} \quad$ While Soviet motives came under increased suspicion when a mission was secretly dispatched from an allied airfield in Italy to the EAM, the main British displeasure was directed towards the Americans. ${ }^{69}$ Churchill became so impassioned in defence of the arrangement that it is easy to get the impression that the idea was his from the beginning, rather than having arisen in the FO. At heart was the developed British view of how to cooperate with the Soviets and how that fitted with their overall vision for a post-war Europe from which the United States could be expected to have retreated. ${ }^{70}$

In the FO, schemes for a post-war Western bloc were now being mooted, and it was hoped that Stalin could be convinced that this was not threatening to the USSR (though the scheme was attractive partly because by containing Germany it also contained the Soviet Union). Indeed they believed from comments he made to Eden back in December 1941 that he supported the idea. As Stettinius had reported, the British conceived the Anglo-Soviet Treaty to be the cornerstone of their European policy - the centre of an arch linking the Western and Eastern European systems. ${ }^{71}$ All except Churchill that is, who saw a Western bloc as so weak as to be a burden and preferred a close Anglo-American relationship and simultaneous interest-based arrangements with the USSR to reduce areas of conflict and preserve vital British interests in Greece and the Eastern Mediterranean. The FO and Churchill, from different perspectives, were looking to limit and define the area of Soviet influence, and to begin to get Soviet acknowledgement of their own, though in neither case considering that these were exclusive zones. There was also a sense that the Soviets' behaviour could be managed if they were committed to concrete arrangements - Stalin, it was sometimes asserted at this time, was a man of his word, once given, and the Soviets seemed to attach significance to proper written agreements. Being treated as equals by the great Western powers would also play to their pride and their inferiority complex and make them likely to limit their own actions because of the prestige and status they were gaining in world affairs in addition to the likely benefits of aid for reconstruction. ${ }^{72}$

While the Americans at times made similar assumptions, the British failed to persuade them to endorse this policy approach. The Americans remained determined that the British should not shape the Soviet policy of the AngloAmerican alliance nor act in any way as the intermediary between the USSR and the USA. ${ }^{73}$ They feared that an acceptance of a Soviet sphere would arouse fears in Western Europe that would lead to a western bloc and a hostile division of Europe ${ }^{74}$ While many in the State Department and White House might well, as Eduard Mark argued, have accepted tacit spheres of interest, provided they were

Alliance: The Internal Dimension of Foreign Policy', in Gabriel Gorodetsky ed., Soviet Foreign Policy 1917-1991 A Retrospective (London, 1994), 99-100; Silvio Pons, 'Stalin and the European Communists after World War Two' Past and Present supplement 6 (2011), 123; Geoffrey Roberts, 'Stalin and the Grand Alliance: Public Discourse, Private Dialogues and the Direction of Soviet Foreign Policy, 1941-1947' Slovo 13 (2001), 8-10.

${ }^{68}$ Churchill to Roosevelt 23 June 1944 FRUS1944:V, 126; Churchill to Eden 10 July and Eden comment, Churchill to Stalin 12 July, Stalin to Churchill 15 July 1944 FO371/43636/R10483; Gilbert, Road to Victory, 1069-71.

${ }^{69}$ Eden to Churchill 8 Aug. 1944 FO371/43636/R11761; Martin H. Folly, 'The Red Air Force in Italy, 1944: A Case Study in the Formation of British Policy to the Soviet Union in World War II', Diplomacy and Statecraft, 11 (2000), 121-4.

${ }^{70}$ Harbutt, Yalta, 139-40.

${ }^{71}$ Stettinius report 7-29 April 1944 FRUS1944:III, 10, 12; draft FO letter to Churchill Sept. 1944 FO371/43306/N6214.

${ }^{72}$ WM(44)157th 27 Nov. 1944 CAB65/48.

${ }^{73}$ Hull to Roosevelt 17 June, Roosevelt to Churchill 22 June, State Department to Soviet Embassy 15 July 1944 FRUS1944:V, 124-5, 130.

${ }^{74}$ Stoler, Allies in War, 186; Lundestad, American Non-Policy, 84, 89-91; John Lamberton Harper, American Visions of Europe (Cambridge, 1994), 99-101. 
sufficiently 'open', the potential ramifications both in western Europe and with American public opinion led them to find the British approach unacceptable. ${ }^{75}$ The Rumania/Greece proposal seemed to stem from the Anglo-Soviet friction that Stettinius had reported, confirmed by the Churchill-Molotov episode, although the British themselves saw it as a means to avoid such friction. To the Americans, there was another way of getting Soviet cooperation: they continued to assert to the British that cooperation in a general security system was the best way of ensuring against the Soviet adoption of the unilateralist option - an eventuality that schemes like the Romania/Greece arrangement appeared to encourage. ${ }^{76}$ They had a point: Churchill's new attitude towards making pragmatic deals and Eden's attachment to the Anglo-Soviet Treaty produced an inclination to bilateralism that in effect conceded some of the gains the Soviets would expect to get from a unilateralist approach, in order to prevent them actually activating such an approach, and thereby preserve cooperation in its broader sense. The Americans, more confident of their power and with a different vision of the future international order, were less prepared to do so and looked to contain the Soviets within a structure of consultation rather than manage divergence by division of prime responsibility.

\section{Conclusions}

Both British and Americans considered that their approach was having the greater success. Hull reiterated to Harriman in September 1944 what Stettinius and the State Department had perceived earlier in the year, namely that the British seemed unaware that Soviet relations with the United States were much better than Soviet relations with themselves. ${ }^{77}$ For their part, the British continued to believe that the Soviets distrusted the Americans more than them, were still worried about US isolationist tendencies, and looked to the Anglo-Soviet alliance to provide them with the assurance of security against Germany that was assumed to be their overriding policy aim. ${ }^{78}$ While Soviet documentation presently available does not fully corroborate that assumption, Ivan Maisky, who knew the British well after ten years in the London embassy, commented, 'The British, knowing Europe better and having more political experience, have made substantially fewer mistakes than their allies in European affairs. The main thing is that they have known how to take account of facts, regardless of whether they like them or not... ${ }^{, 79}$

Stettinius made a firm statement of the State Department's desire to keep U.S. policy distinct from that of the British to Roosevelt on 8 November 1944,

While the Government of the United States is fully aware of the existence of problems between Great Britain and the Soviet Union, this Government should not assume the attitude of supporting either country as against the other. Rather this Government should assert the independent interest of the United States (which is also believed to be in the general interest) in favor of equitable arrangements designed to attain

${ }^{75}$ Eduard Mark, 'American Policy Toward Eastern Europe and the Origins of the Cold War, 19411946: An Alternative Interpretation' Journal of American History 68 (1981), 313-36; Mark,'October or Thermidor', 949-50.

${ }^{76}$ Harriman to Hull 9 Jan. 1944, 9 Feb. 1944, 10 Sept. 1944 FRUS1944:IV 801-2, 826, 988

${ }^{77}$ Hull to Harriman 18 Sept. 1944 FRUS1944:IV 991.

${ }^{78}$ Warner to Balfour 10 Aug. 1944 FO371/43413/N3982. Balfour replied that 'Generally speaking they [the Soviets] regard us as persons with whom it is easier to get on as man to man than with the Americans. They think of us as fellow Europeans... a people who, like themselves, have directly experienced enemy action,' to Warner 9 Oct. 1944 FO371/43306/N6565.

79 A. Filitov, 'Problems of Post-war Construction in Soviet Policy Conceptions during World War II' in F. Gori and S. Pons eds, The Soviet Union and Europe in the Cold War, 1943-53 (London, 1996), 11 . 


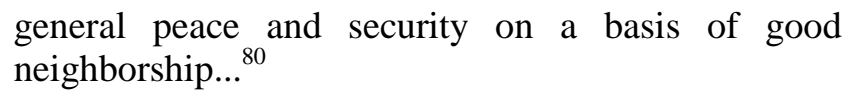

Both British and Americans continued therefore to question each other's approach. Their policies remained parallel but separately constructed and at odds at significant points. Where they tried to influence each other they largely failed. Even Churchill, in Moscow in October 1944, was not above forging ahead with bilateral arrangements without consultation with the Americans. ${ }^{81}$ The American and British foreign policy bureaucracies continued consciously to pursue separate lines of policy. In this important instance, the Anglo-American partnership was well short of the coordinated integrated coalition that it had become in the military sector, in which policies were made jointly. The two bureaucracies, in their selfsatisfied comments that they were doing better than the other in their handling of the Soviets, were clearly happy with this. They found a justification for these separate policies, where it was needed, in the concept of a Soviet fear of Allied 'ganging-up,' but from the documentary record, this does not suffice as the sole explanation for the separation between British and American policy approaches. It served to obscure differences of approach and objective, and in particular a belief on both sides of the Atlantic that the other's approach was both wrong and failing. These shared convictions drove all parties to keep the issue separate when so many others were being subject to a joint approach.

It is evident that the difference between American and British policy formulations is not easily reducible to a formula that divides them on the issue of taking a 'hard' or 'soft' line towards the USSR. The common assertion that British policy had moved to a hard line during 1944 - partly in response to being kept at arm's length by the Americans at the Teheran conference, though mainly in response to Soviet advances into Eastern Europe and the Balkans - does not fit the actual British policy debate. It is mainly based on certain well-known statements by Churchill. The views of others in his government need to be taken into account, and the context of his comments needs to be understood. Moreover, Churchill was by no means consistent. Most importantly, and this applied both sides of the Atlantic, and in the respective embassies and missions in Moscow, a policy recommendation of 'firmness', did not signify the adoption of Cold War attitudes. It was a tactic to achieve cooperation and Soviet behaviour modification, and was not based on the assumption that cooperation was impossible. Its application varied between agencies and key actors - a facet obscured by the shared vocabulary used.

The British and Americans had developed a range of views on how the alliance with the Soviets should be articulated, and, indeed, saw large implications for their own relationship in the format of that one. In particular, the issue of how best to handle the Soviets was influenced by a combination of views of each others aims and objectives taken concurrently with assessments of the aims of the Soviet leadership. There was interpenetration of ideas, but this did not prevent divergences on key policy issues, with little concerted attempt to resolve them. When it came to relations with the third great ally, the British and Americans, while both talked at times of the need for coordination, when the opportunity to coordinate policies arose, in April 1944, preferred to operate outside the context of the special relationship that characterised other aspects of their wartime partnership.

\footnotetext{
${ }^{80}$ Stettinius memorandum 8 Nov. 1944 FRUS1944:IV, 1025.

${ }^{81}$ Churchill to Attlee 18 Oct. 1944 CAB120/165; K. G. Ross, 'The Moscow Conference of October 1944 (Tolstoy)' in Deakin et al, British Political, 73-6.
} 